\title{
A térszerkezet és a geoökonómia
}

\section{Spatial structure and geo-economics}

\author{
SIMAI MIHÁLY
}

SIMAI Mihály: kutató professzor emeritus, MTA Közgazdaság- és Regionális Tudományi Kutatóközpont, Világgazdasági Intézet, Budapest, simai.mihaly@krtk.mta.hu

KULCSSZAVAK: világgazdaság, térszerkezet, transzformáció, geopolitika, hatalmi viszonyok, demográfia, verseny

ABSZTRAKT: Az elmúlt néhány évtizedben kibontakozott és folytatódó transzformációk, mindenekelőtt a globalizáció, a hatalmi viszonyok átalakulása, az éleződő verseny, a demográfiai változások, a tudásalapú társadalom kibontakozása sokoldalúan befolyásolják bolygónk térszerkezetét. A változások új követelményeket támasztanak a földrajztudományban és a kapcsolódó területeken folyó tudományos kutatásokkal szemben. A geopolitika mellett kialakult fiatal tudományterület, a geoökonómia a transzformációk, a gazdasági folyamatok és a térbeli viszonyok kölcsönhatásainak feltárásával és az államok ezzel összefüggő stratégiájának kérdéseivel foglalkozó diszciplína. Az Enyedi György professzor emlékére készült tanulmány e diszciplína kifejlődésének hátterét megvilágítva fogalmazza meg a feladatokat a 21. század világának feltételei között.

Mihály SIMAI: research professor emeritus, Institute of World Economics, Research Centre for Economic and Regional Studies, Hungarian Academy of Sciences, Budapest; simai.mihaly@krtk.mta.hu

KEYWORDS: world economy, spatial structure, transformation, geopolitics, power relations, demography, competition

ABSTRACT: This paper is based on a lecture delivered at the scientific conference devoted to the commemoration of professor György Enyedi. He was a pioneer among the geographers in studying the role of spatialization of political and economic processes, and dealing with the main issues of geography in a comprehensive, interdisciplinary framework. His international role was also very important in a rational change in social sciences: rediscovering the territorial embeddedness of globalization and, particularly, of political and economic factors.

The process of global transformations has been probably the most important underpinning of this change. Geostrategic and technological changes have a major influence on the international order and on those forces shaping the processes leading to a new order. The present changes are of epoch-making importance. Indeed, the world is in a state of transition to a new historical order, the parameters and regulating forces of which remain to be determined, though it seems likely that it is an order of dynamic, fluid, and rapidly fluctuating processes difficult to fully apprehend and control. Thus it is necessary for the world to embrace collective multilateral governance to manage those factors of instability and risks already visible in the system, with the aim of promoting more efficient conflict prevention, building multilateral cooperation regimes and facilitating risk management. The last stage of the 20th century and the

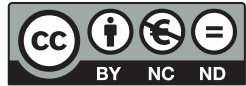


first decades of the 21st will most probably be considered by future historians as a rare and more or less unprecedented coincidence of different major changes evolving in a number of critical areas in the globalization process: population trends, the global power structure, politics, economics, science, technology, environment and governance. Each one of these changes can be characterized as transformations in a given important area. The historical coincidence, interactions and consequences of these transformations are extremely rare developments in human history. It is a fundamental task for the global community to sustain relatively peaceful relations by defusing potentially explosive situations and averting major crises. Also, it is important to promote the sustainability of global development by finding solutions to global demographic, socio-economic and environmental problems in an increasingly diverse and interconnected world of close to 200 political units and more than 7 billion people. All these made the spatial consequences of transformations fundamentally important for global politics, economics and also for scientific research. An important concept, which may develop into a new discipline which interconnects international economics, economic statecraft and foreign policy, national and global security, is "geo-economics". It may grow to be a very important field of social sciences in a transforming world which will become unrecognizable by the middle of the 21st century.

Az elmúlt évtized egyik igen érdekes fejleménye a „térbeliség” jelentőségének és a földrajztudomány fontosságának újrafelfedezése a társadalomtudományokban és azoknak az államközi szervezeteknek kutatásaiban, amelyek korábban, a globalizáció egyik következményeként úgy gondolták, hogy az államhatárok háttérbe szorultak és a technikai fejlődés nyomán a távolság mint tényező elvesztette szerepét a gazdasági kapcsolatrendszerben. A politikatudományban az ideológiai tényezők jelentőségének csökkenésével ismét előtérbe került a geopolitikai megközelítés a nemzetközi politikai viszonyok és stratégiák alakításában. A jelenleg is folytatódó vita a földrajzi tényező, a térbeliség és a térszerkezet fontosságáról a gazdasági fejlődésben az Amerikaközi Fejlesztési Banknak egyik 2000-ben megjelent igen érdekes tanulmánya nyomán bontakozott ki, amelynek az Is geography destiny? címet adták. (Ezt magyarul talán úgy lehet fordítani, hogy Sorsdöntö-e a földrajzi fekvés?) A tanulmány szerzője a földrajztudományból kiindulva a következőket írta: A földrajztudományt mint hatalmas diszciplínát, amelyik valaha a tudományok élvonalában állt, más tudományágak háttérbe szorították. Jelenleg sokan tekintik ódivatúnak a földrajzot, amely számukra az elnyütt tankönyvek és pasztellszínű térképek előtt merev arccal magyarázó tanárok képzetét kelti. Mások inkább gyanakodva idézik a korábbi időket, amikor a földrajzot eszköznek tekintették olyan Európa-centrikus elő́téletek kialakítására, amelyek a trópusi éghajlatot összekapcsolták „alsóbbrendű fajokkal”. A tanulmány kifejti, hogy a földrajzi tényező, a térbeliség és egy adott közösség „elhelyezkedése” - ha magában nem is ad kielégitő magyarázatot számos politikai, társadalmi vagy gazdasági folyamatra - mindig is fontos volt, a jelenlegi feltételrendszerben igen lényegessé vált. 2003-ban Peter Dicken angol közgazdász Global shift címü könyvében - amelynek alcíme A világgazdaság térképének átalakulása volt - egyrészt túlzottnak tartotta a globalizációnak tulajdonított változásokat, másrészt hangsúlyozta annak tér- és időbeli egyenlőtlenségeit (Dicken 2003, 11-12.). Hat évvel később a Világbank éves jelentése (World Bank 2009), a World Development Report címe Reshaping economic geography, A gazdaságföldrajz átformálása volt. Közpon- 
ti témái a sürüsödés, a távolság és a megosztottság fogalmait, vagyis a 21. század legátfogóbb társadalmi és gazdasági kérdéseit taglalták. A jelentés kiemelte: a világtermelés fele bolygónk területének 1,5\%-ára összpontosul. Észak-Amerika, Európa és Japán a világvagyon kétharmadával rendelkezik. Ezek a számok a megosztottságot és az ezzel összefüggő súlyos problémákat is jelzik. A szállítást és az emberek mozgását elősegítő és költségeiket csökkentő hatalmas technikai átalakulás az információs forradalommal kombinálódva minden eddiginél nagyobb mértékben hozta közelebb egymáshoz a kontinenseket, az államokat, a társadalmi, politikai és gazdasági változások helyi, regionális és globális dimenzióit. Mindezek ugyanakkor növelték a megosztottságot, a távolságot az emberek és közösségeik életfeltételeiben.

A hazai világgazdasági kutatások a 21. századra vonatkozóan ugyancsak aláhúzzák, hogy új jelentőségük lesz az éghajlati viszonyoknak, a tengerek vagy nagy folyók által teremtett lehetőségeknek, a határok értelmezésének s bizonyos térségekben a „szomszédság” szerepének is. Ezek a tényezők - párosulva számos más változással - növekvő szerepet játszanak a különböző közösségek életviszonyainak formálódásában, társadalmak és gazdaságok fejlődésében, kapcsolatainak építésében vagy konfliktusaiban. Kihatnak a belső és a nemzetközi migrációra és az urbanizációs folyamatra is. Sajátos és sokrétű kérdéskört jelent a folyamatok diffúziója, valamint a tér és az idő összekapcsolódása a világgazdaság fejlődésében.

Tanulmányom Enyedi György professzor emlékére 2013. április 20-án a Magyar Tudományos Akadémián szervezett tudományos konferencián ezekkel a témakörökkel foglalkozott. Enyedi György munkásságát a Föld mezőgazdasági viszonyainak elemzésében, az urbanizációban vagy a legkisebb települések esetében azért tartottam mindig is érdekesnek a világgazdasági kutatások számára, mert a földrajzi, történelmi, társadalmi és gazdasági változásokat komplex rendszerben vázolta fel. Tulajdonképpen sok tekintetben megelőzte azokat a felismeréseket, amelyeket a közelmúlt vitái megfogalmaztak.

\section{A világgazdaság, a „tér” és a globális transzformációk}

A világgazdaság olyan sajátos, sokdimenziós, komplex rendszer, amelyet több szinten különböző erejű „szereplők” formálnak (Simai 2008). Érdek- és értékviszonyaik különböző nagyságú térségekhez kapcsolódnak, és a köztük kialakult kapcsolódások és kölcsönhatások változásai a világ politikai és gazdasági struktúráját szinte állandó változások állapotában tartják. A komplexitás azonban nem csak ezt jelenti. A komplex rendszerek nem egyensúlyi viszonyokon nyugszanak, amelyekre lineáris változások jellemzők. Egyidejüleg különböző irányú változások hatnak a rendszer müködésére. Egyes változások, illetve következményeik többé-kevésbé előre jelezhetők, mások váratlanok és meglepetésszerü 
következményekkel járnak. A komplex rendszerek másik fontos jellemzője az azonos és ellentétes érdekű tagjai és folyamatai közötti visszacsatolások és kölcsönhatások érvényesülése, amelyet a rendszerbe lépők és az abból kiesők állandó mozgásban tartanak. A 21. század világának központi folyamatai - és különösen a változások - nem függetleníthetők a rendszer lényeges „szereplőitől”, amelyek között az államok továbbra is meghatározó fontosságúak a világpolitikában és a világgazdaságban. A globalizációs folyamat államokhoz kötődik, s az átalakulások, a transzformációk összessége ezek talaján formálódik globális trendekké és problémákká. A különböző jellegű, politikai és gazdasági határokkal definiált térszerkezet ebben a rendszerben sajátos és fontos tényező. Azok a megközelítések, amelyek a globális rendszer elemzésénél a térbeliséget nem veszik figyelembe, szükségképp „légüres térben” mozognak.

A rendszer komplexitása és a tér jelentőségének alakulása leginkább azokkal a globális transzformációkkal és problémákkal jellemezhető, amelyek a 21. század első évtizedeit is meghatározzák. Kibontakozásuk jórészt a 20. század utolsó harmadában kezdődött vagy vált intenzívebbé. Egyes területeken a transzformációk viszonylag lassan, fokozatosan mentek végbe, s szerepük volt bennük az államok vagy a világrend más szereplői döntéseinek. Más transzformációk hirtelen és váratlan változások, amelyekre a világ nem volt felkészülve. Nem volt felkészülve az emberiség ezek történelmi egybeesésének, kölcsönhatásainak következményeire sem.

A transzformációk között első helyen említem a globalizációt, mert ez a világ fejlődésének szinte valamennyi tényezőjét és területét befolyásolja. Tényezői döntő szerepet játszottak a 21. század világgazdasági válsága, a „nagy válság" gyors átterjedésében az Egyesült Államokból a világ többi fejlett államába s végül minden kontinensre. Közgazdasági szempontból a globalizáció a nemzeti gazdaságok összekapcsolódása és kölcsönös függőségének elmélyülése, amely a gazdasági áramlások liberalizálásával párosul. Így egy ország gazdasági tevékenységeinek kedvező és kedvezőtlen következményei gyorsan terjednek át más országokra, térségekre, sőt az egész világgazdaságra a nemzetközi kapcsolatok különböző területei és a világvállalatok révén. A globalizálódás folyamata kiterjed a politikára, a kultúrára, a tudományos és technikai fejlődésre, fö területe azonban a gazdaság - ezen belül is a pénzpiacok és a technikai fejlődés. A 21. században a globalizációt tovább mélyítette az infokommunikációs hálózatok nemzetközi rendszere. A globalizáció nyomán gyökeres átalakulás ment végbe a nemzetközi munkamegosztás területi, ágazati és szervezeti viszonyaiban, az emberek fogyasztási szokásaiban. A tömegkommunikációhoz is kapcsolódó és nagymértékben szervezett demonstrációs hatás a globalizáció társadalmi következményei terjedésének egyik jelentősebb motorja. A globalizáció egyik fontos jele és döntő tényezője annak is, hogy a gazdasági és társadalmi fejlődésben számos közös gond jelent meg, amelyek az egész emberiséget érintik, s kezelésük, megoldásuk csak globális együttműködéssel lehetséges. Sokan a nagy járványok megjelenését és elterjedését, illetve ennek veszélyét tekintik a globá- 
lis problémák „ősének”. Ez nem irreális feltételezés, és a világjárványok veszélye továbbra is fennáll. Különbséget kell tenni azonban a természeti katasztrófákkal, a járványokkal összefüggő és az ember alkotta globális problémák között. Ez utóbbiakkal kapcsolatban a 20. században bolygónk leglényegesebb globális problémájának tartottam a tömegpusztító fegyverek megjelenését, terjedését és az emberiség kiirtásával fenyegető nukleáris világháború veszélyét. A 21. század jelenlegi feltételei között bolygónk környezeti viszonyainak romlása a legfontosabb globális probléma, amelynek következményei nemcsak az emberiséget, hanem az egész bioszférát fenyegetik. Fontos változás a múlthoz képest, hogy a 21. században az emberiség többé nem védtelen a globális problémákkal szemben. Kialakultak azok az együttmüködési formák és szervezetek, amelyek ezek felismerésében, a problémák előrejelzésében és a közös fellépésben fontos szerepet játszhatnak. Döntő többségük az ENSZ „családjának” keretei között működik. Az ENSZ és szakosított szervezetei az emberi tevékenységek szinte valamennyi területét átfogják, a világegészségügytől a világűrig. Hatékonyságuk azonban nem függetleníthető a tagállamok magatartásától, amelyeket érdekeik, értékeik és lehetőségeik gyakran ellentétes irányban befolyásolnak. A globalizációs folyamatot a jövőben is rendkívül bonyolulttá és ellentmondásossá teszi a világgazdaság meghatározó magasan fejlett államainak, gazdasági szempontból életképtelen mini- és mikroállamoknak, sok százmillió embert tömörítő gazdasági törpéknek, kis területű és lakosságú gazdasági óriásoknak egyidejü létezése és érdekeik ütközése.

A globalizációs folyamat forrásai, jellege és hatásai szorosan összefonódtak a második nagy jelentőségű transzformációval, amely a világ politikai térképét rajzolta át. A Szovjetunió szétesése nyomán lényegében lezárult a nagy modern gyarmatbirodalmak fél évezredes korszaka. A második világháború után kialakult „két világ” helyébe ismét a világkapitalizmus globális rendszere, ennek érdek- és értékviszonyai léptek. Áttekinthetetlenebbé és bonyolultabbá teszi azonban a világfejlődést az a tény, hogy a 21. század globális kapitalizmusa mint rendszer lényegesen differenciáltabb, mint korábban: többé nem a korábbi, döntően európai kapitalista modell jellemzi. A kapitalizmus különböző válfajaiban és reinkarnációiban történelmi és társadalmi sajátosságok, fejlettségi szintkülönbségek és más gazdasági adottságok mellett jelentős a térbeliség is. A „két világ” eltünése nyomán a "harmadik világ” mint politikai kategória elvesztette „értelmezhetőségét”. Államai lényegében éppúgy „beleolvadtak” a szuperkapitalizmus új globális rendszerébe, mint a volt szocialista országok. Mindezek nyomán a globális rendszer új gazdasági és hatalmi hierarchiája épült ki. Ennek belső feszültségei, ellentmondásai, egyenlőtlenségei és dinamizmusai határozzák meg a 21. század fejlődését. Az új struktúra kibontakozását meggyorsította a világgazdaság 2007-ben kezdődött válsága és a nyomában kibontakozott tartós pangás. Ennek egyes következményei különös erővel és egyenlőtlen mértékben hatottak a hatalmi rendszer fejlett, vezető államaira. Ilyen volt a példátlan vagyonvesztés, amelyről továbbra sincs megbízható adat. (A becslések szerint ez 
15-30 ezermilliárd dollárra tehető.) A nemzetközi pénzügyi rendszerben egyensúlyi zavarok, kaotikus viszonyok bontakoztak ki, hatalmas mértékben megnövekedett az eladósodás, amely az államokat, a vállalatokat, különösen a bankokat és a lakosságot elsősorban Európában sújtotta. A túltermelés, a termeléscsökkenés, a gazdasági növekedés tartósan alacsony üteme, stagnálása és a jelentős méretűvé vált munkanélküliség lényegében ugyancsak a fejlett államok helyzetét és pozícióit gyengítették. Jelentős veszteségek érték a fejlett országok hatalmas pénzügyi konglomerátumait és számos nagy nemzetközi társaságát is. Ez utóbbiak számottevő stratégiaváltásra kényszerülve viszonylag gyorsan tudtak reagálni a változásokra. Alacsony hatékonyságúnak bizonyultak a multilaterális együttműködés szervezetei is. Ezek a problémák az Egyesült Államokban a külpolitika és a háborúk magas költségeivel és kudarcaival párosultak. A válság utáni világ politikai és gazdasági hatalmi viszonyai röviden úgy foglalhatók össze, hogy a szuperkapitalizmus globális rendszerében folytatódik a tőke gyors felhalmozódása és a gazdasági hatalom ennek megfelelő növekedése a hagyományos nyugati világon kívüli térségekben. 1995-ben a 26 leggazdagabb ország még a globálisan felhalmozott tőke 85\%-ával rendelkezett. Az elmúlt 15 év során ez az érték 75\%-ra esett vissza. Ezt a folyamatot a válság valamelyest gyorsította. Egyik leglényegesebb tényező az átalakulásban Kína rendkívül gyors gazdasági fejlődése. A Kínai Népköztársaság viszonylag rövid időn belül uralkodó szerepet játszik majd a világgazdaságban, s nemcsak termelésének volumene, hanem a világkereskedelemben, a külföldi befektetésekben betöltött szerepe alapján is, s mint a világ nyersanyagainak hatalmas fogyasztója és a globális környezeti problémák egyik lényeges új forrása. Magyarország számára ezek a változások - amelyek következményei bonyolultabbá és bizonytalanabbá tették a fejlődés távlatait - különösen azért fontosak, mert sokoldalúan befolyásolják az Európai Unió helyzetét és jövőjét. Az EU csak viszonylag lassan képes alkalmazkodni az új globális feltételekhez. Ennek oka mindenekelőtt az, hogy tagállamainak helyzetét és érdekviszonyait e globális változások eltérő módon és mértékben érintik. E tekintetben jelentősek a különbségek a vezető európai államok és vállalataik versenyhelyzetében, eltérőek azonban a kisebb országok pozíciói is. EU-tagságunk és a transznacionális társaságok Magyarországra települt leányvállalatai révén az EU és a vezető hatalmak helyében, helyzetében, szerepében és kapcsolataiban végbemenő globális változások közvetlenül hatnak hazánkra is.

A transzformációk további döntő fontosságú területe az emberiség jövője szempontjából különösen jelentős demográfiai átalakulás, amely átrajzolja a világ népesedési és etnikai térképét. A demográfiai változások több vonatkozásban is szoros kölcsönhatásban vannak a világfejlődés társadalmi-politikai és gazdasági rendezőerőivel. A demográfiai átalakulás többdimenziós. Az egyik dimenzió a népszaporulat. A világnépesség növekedésének lassulása folytatódik, a 21. század ötvenes éveire valószínűleg befejeződik a világon az átmenet egy új demográfiai korszakba, és lezárul egy többszáz éves ciklus (Malthus 1798). A 21. század köze- 
pére Földünk népessége 9 milliárd fö körül stabilizálódik. ${ }^{1}$ Addig azonban két jelentős változás következik be. Az egyik a fejlett országokban lesz jellemző, ahol a lakosság stagnálása, csökkenése és elöregedése, a munkaképes korúak arányának zsugorodása jelentkezik. Ez a folyamat a fejlett országokban lényegében a 20. században kezdődött, sőt olyan fejlődő országokban is megindult, amelyek jelentős erőfeszítéseket tettek a népszaporulat csökkentésére. A következő fél évszázad során pl. az Európai Uniót 2013-ban alkotó térség népessége valószínűleg 40-50 millió fövel csökken (Simai 2008; United Nations 2013). ${ }^{2}$ A kelet-európai országokban a csökkenés még nagyobb lehet. A 21. század második felében a demográfiai átalakulás globálisan is jellemzővé válik. A másik tendencia a demográfiai polarizáció. Ennek lényege, hogy a világnépesség növekedése a következő évtizedek során döntő részben a szegény országokban történik. Az ENSZ demográfiai előrejelzései szerint a Föld népessége várható növekedésének 95-98\%-a az alacsony jövedelmű országokban megy végbe. A következő harminc esztendő során évente várható mintegy 78 millió új földlakó közül kb. 40 millió 5 országban látja meg a napvilágot: Indiában, Kínában, Pakisztánban, Indonéziában és Nigériában. Ez a 21. század demográfiai kihívásának legfontosabb összetevője.

A korösszetétel átalakulása a változások igen lényeges következménye. Az új népesedési korszak sok új feladat megoldását követeli meg, és kevés reális alternatívát enged. Azokban az országokban, amelyekben a népszaporulat gyorsabb marad, hatalmas mértékben megnő a munkaképes korúak aránya. Ezek számára minden korábbinál nagyobb tömegben kellene munkahelyeket vagy megélhetési lehetőségeket biztosítani. Évtizedenként 4-500 millió új munkahelyre lenne szükség a következő két-három évtizedben. Erre az érintett országok csak jelentős társadalmi reformokkal s nagy volumenű külföldi segítséggel lennének képesek. A 2007-ben kibontakozott világgazdasági válsággal kialakult munkanélküliséget különösen súlyossá és szinte kezelhetetlenné tette az, hogy a 21. századra egy sajátos foglalkoztatási válsághelyzet alakult ki, amelynek következményei globálisak. A fejlett országokban a követelmények és a feladatok között egyre nagyobb hangsúlyt kap a generációközi gazdasági és társadalmi kérdések megfelelő kezelésének szükségessége. Nem áll érdekében az országoknak például, hogy a korösszetétel változása rontsa a következő nemzedékek lehetőségeit életfeltételeik javítására, s ily módon új generációs konfliktusokat építsen a társadalomba. A generációs konfliktusok egyik lehetséges forrása az, hogy a csökkenő arányú hagyományos munkaképes korú korosztályoknak több embert kell eltartaniuk. Kialakul ugyan egy új, lényegében munkaképes korcsoport, az „idősebb középkorúak” csoportja, akik számára viszont új típusú munkalehetőségeket kellene teremteni. Az eltartandók nagyobb hányadát a legfiatalabb korosztály, a gyermekek alkotják, azonban nő az idős korosztályok aránya is. A generációs konfliktusok sajátos forrása lehet a technikai fejlődés. A tudományos és technikai változások jellege, az új technológiai generációk gyorsabb megjelenése számottevően növelik a fiatalabb nemzedékek fontosságát az emberi erőforrások kezelésében. A fiatalabb generációk rugalmasabbak, könnyebben képesek befogadni és müködtetni az újat. A technikai 
fejlődés - és ezzel összefüggésben a társadalmi munkamegosztás - átalakulása felgyorsítja a nők egyenjogúságának és társadalmi részvételének megváltozását. A munkaképes korúak arányának csökkenését ellensúlyozó lépések között jelenleg több alternatíva foglalkoztatja a szakembereket. Az egyik az államok radikális beavatkozása a demográfiai folyamatokba a népszaporulat növelése érdekében, legalábbis azokban az országokban, ahol a lakosság csökkenése különösen jelentős méreteket ölt. Ez vagy drasztikus beavatkozást követel az egyének és a családok életébe, a jövedelmek elosztásába, vagy pedig különleges ösztönzőket. A másik alternatíva az, hogy a technikai fejlődés gyorsításával növeljék a munkaképes korúak termelékenységét és az általuk megtermelt elosztható új értékek mennyiségét. Ily módon nagyobb számú eltartottról tudnak gondoskodni a dolgozó korosztályok jelentősebb megterhelése nélkül. Lényegében az ún. új középkorúak és a nők munkába állása is az eltartási terhek csökkenését jelenti. Mindez azonban megköveteli a képzési rendszernek és a társadalmi munka szervezetének átalakítását. A harmadik alternatíva a bevándorlás szabadabbá tétele az érintett országokban.

A demográfiai átalakulás másik dimenziója a belső és nemzetközi migrációra vonatkozik, amely a 21. század egyik legnagyobb jelentőségü globális kérdésévé vált. A 21. században a népvándorlást kiváltó vonzó- és taszítóerők lényegesen intenzívebbé váltak. Vonzó- és taszítóerők természetesen mindig is léteztek a világban. A taszítóerők döntően a világ demográfiai és gazdasági polarizáltságának erősödésével kapcsolatosak. A közlekedési technika fejlődése tovább könnyíti és gyorsítja az emberek nagy távolságú mozgását. Erősödnek a globális telekommunikációs rendszereken keresztül terjesztett demonstrációs hatások, amelyek a nyugati világ magasabb életszínvonalát propagálják. Az iskolázottság, a képzettség terjedése a fejlődő világban szélesebb rétegek mobilitását növeli. A bevándorlás egyes országokban a munkaképes korúak arányának és abszolút számának csökkenése miatt válhat szükségessé. Kérdéses ugyanakkor, hogy az egyetemes emberi jogok nagyobb mértékü tiszteletben tartása és a demokrácia a fejlett ipari országokban milyen mértékben lesz képes ellensúlyozni a kevésbé fejlett térségekből eredő migrációt erőszakosan korlátozó társadalmi és politikai törekvéseket.

A demográfiai transzformáció harmadik dimenziója a településrendszer átalakulása. 100 évvel ezelőtt a világ lakóinak négyötöde falusi településeken élt. A globális adatok szerint 2011-ben történt meg az „urbanizációs fordulat”, a városok lakóinak aránya meghaladta a népesség $50 \%$-át. Ha a városokba irányuló migráció a jelenlegi ütemben folytatódik, 2050-re a városi lakosok aránya meghaladja majd a 75\%-ot, Afrikában 2012-höz képest háromszorosára, Ázsiában kétszeresére nő. A folyamat a világ fejlődő térségeiben inkább volt jellemezhető deruralizációként, mint klasszikus értelemben vett urbanizációs folyamatként, jóllehet egyes szakemberek a „szuperurbanizáció” korszakának tekintik a kialakuló szakaszt. Egyrészt a városi és a falusi jellegű települések között új kölcsönhatások alakulnak ki, s ennek, valamint más társadalmi, gazdasági és technikai 
tényezők hatására gyorsul mindenütt a hagyományos falusi életformák felbomlása. Másrészt az elvándorlást a falvakból a fejlődő világ legtöbb új metropoliszában nem kíséri a városi munkalehetőségek növekedése és az urbanizált életmód terjedése. A fejlődő országokban hatalmas megavárosok alakulnak ki, amelyek körül viskókban és barakkokban élő milliók koncentrálódnak. A falusi szegénység növekvő mértékben helyeződik át a városi településekre, degradálva azokat. 2010-ben több mint nyolcszáz millióan éltek nyomortelepeken. 2040re számuk meghaladja a kétmilliárdot, amely az akkori világnépesség közel negyedének felel majd meg. A társadalomtudományok szinte valamennyi ága számára fontos kérdések egész sora fogalmazódik meg. Egyebek között: Hogyan befolyásolja a településrendszer átalakulása a nők társadalmi helyzetét és szerepét? Milyen következményekkel jár a deruralizáció a családok jövőjének alakulásában? Miként módosítja az átalakulás a politikai folyamatokat? Miképpen járulnak hozzá a metropoliszok a természeti feltételek romlásához és hatalmas katasztrófákhoz? A megavárosok egyben új gazdasági és hatalmi központok is. Igen jelentős az urbanizációs folyamat hatása a makrogazdasági, felhalmozási, beruházási és jövedelemelosztási viszonyokra is. A nemzetközi migráció döntő mértékben a városi településeket veszi célba. Miképpen lehet megakadályozni egymással harcoló etnikai gettók kialakulását? Rendkívül súlyos gond a falvakból elvándorolt népesség élelmezése, hiszen a mezőgazdaság sok országban a falvakat is alig tudja élelmezni. A viskó- és barakkvárosok jogi státusza, a deruralizáció mint a bűnözés, az erőszak és a terrorizmus terjedésének forrása ugyancsak lényeges problémák. Az új települések azonban nem csak a nyomort növelik. Jobb lehetőséget lehetne teremteni az ott élők képzésére, egészségügyi ellátására. Súlyos gond az is, hogy a viskó- és barakkvárosok zöme a természeti katasztrófáknak kitett árterületeken, kopár hegyoldalakon jön létre. A fejlödő világ csaknem ötven megavárosa gyakori földrengéseknek kitett területeken létesült. A deruralizáció hatásain túl a természeti katasztrófák társadalmi hatásaival és kezelésük növekvő költségeivel is számolni kell.

A globális transzformációk sorában a jövőben különösen nagy jelentőségű a tudásalapú társadalom és gazdaság kibontakozása (Simai 2008). Ez az átalakulás minőségileg új kérdéseket állít a társadalmak elé. Nyilvánvaló, hogy bizonyos tudásra, illetve a felhalmozott ismeretek hasznosítására minden eddigi társadalomban szükség volt. Tulajdonképpen minden gazdasági tevékenység az emberiség történetében valamilyen tudásra és információra épült. A múltbeli viszonyok és a 21. századra jellemző feltételek között mindenekelőtt az a különbség, hogy a korábbi időkben a tudás döntően tapasztalatokra épült, s nem a tudomány egyre bővülő eredményeire. Az oktatás - és különösen az egész életen át tartó képzés - kihívássá, egyszersmind a siker feltételévé is válik. A jó minőségü alapképzés kitűnő hosszú távú befektetésnek bizonyult a fejlődő világban a szegénység elleni küzdelemben. Azok az emberek, akik a tudást használják munkájukban (a tudásdolgozók), az őket menedzselők (a tudásmenedzserek) és azok, akik a tudást produktív célokra „elhelyezik”, döntő fontosságú társadalmi csoportokká váltak. Mellettük 
egy hatalmas társadalmi csoport nőtt ki a szolgáltatásokban és a kisegítő tevékenységekben, akik nem rendelkeznek a szükséges tudással. A jövő globális rendszerébe való integrálásuk alapvető társadalmi probléma és kihívás. A fejlett országokban nő a tudásdolgozók száma; Peter Drucker (1999) szerint a 20. század végén az Egyesült Államok munkaerejének már a kétötödét alkották.

A 20. század második felétől különösen jelentőssé váltak a tudományos kutatások az új tudás „termelésében”. Drucker a tudomány és a tudás önálló szerepét is hangsúlyozza. A 21. század világgazdasági fejlődését meghatározó tényezők között minden korábbinál nagyobb jelentőségű lesz az államok differenciálódásában és a vállalatok közti versenyben a képesség az új tudás tömegének bővítésére, valamint a tudományos és technikai fejlődés eredményeinek felhasználására. A gyors és szélesedő bázisú technikai fejlődés hatalmas változások forrása a világgazdaságban, amely történelmileg példátlan lehetőségeket nyit az emberiség számára a jólét növelésére. A globalizáció folyamatának egyik alapvető tényezője a szállítás és a kommunikáció költségeinek csökkentése, a nemzeti gazdaságok közötti kapcsolatok további erősítése, beleértve a transznacionális tőke- és technológiaáramlást és tulajdonviszonyokat. A technológiai fejlődés új szakasza nagymértékben hozzájárul a világgazdaság földrajzának átalakulásához, és új kompetitív előnyök létrehozásával dinamizálja a globális versenyt. Gyorsul a hagyományos szektorok és iparágak átalakulása, új ipari és szolgáltató ágak létrejötte. A technikai átalakulás a nemzetközi versenyben jelentős előnyökhöz juttatott egyes országokat és vállalatokat a katonai és a polgári termelésben, s minden korábbinál jobb lehetőséget nyitott számukra a globális expanzióra. A légi közlekedés és szállítás globális kiterjedtsége, a hatalmas konténerszállító hajók, a szupertartályhajók, a szállítás, a közlekedés és a távközlés integrálódása, az információs forradalom ugrásszerüen fejlődő technikájával lényegesen gyorsabbá, olcsóbbá és biztonságosabbá tette a pénz, az áruk, a tőke, a tudás, a technika és az információk nemzetközi áramlását, hatalmas távolságok áthidalását. Mindez radikális változásokat tett lehetővé a nemzetközi menedzsmentben, új lehetőségeket nyitott a vállalati hálózatok számára. Ezt nemcsak a fejlett világ legnagyobb társaságai voltak képesek hatékonyan hasznosítani, hanem a fejlődő országok gyorsan nemzetköziesedő nagyvállalatai is. Mindez új, kemény feltételeket teremtett a nemzetközi versenyben, ugyanakkor a fejlett világ kisebb vállalatai számára szintén könnyebbé vált a hozzáférés a nemzetközi kutató, fejlesztő és logisztikai hálózatokhoz. A fejlődés élvonalában álló országok és nagyvállalataik igyekeznek megőrizni versenyelőnyeiket, ami növekvő erőfeszítéseket követel tőlük. A fejlődő és közepesen fejlett országok és vállalataik számára különösen kemény kihívás a nemzetközi verseny e szakasza. A tudásalapú társadalom kibontakozása az egyes térségekben és államokban az intézmények és az egyének helyzetét és esélyeit illetően is rendkívül egyenlőtlen. A hozzáférhetőség mértékének térképe bolygónkon hatalmas egyenlötlenségeket mutat. Mindenütt megnövelte azonban az oktatási rendszer fontosságát. A tudásalapú gazdaság és társadalom 
kibontakoztatásában és a kialakult egyenlőtlenségek mérséklésében meghatározó fontosságú a felsőoktatás globális terjedése és minőségének átalakulása. Ennek folyamata a 20. század utolsó harmadában gyorsult fel. A 21. század első évtizedének végén a Föld 203 országában, illetve önkormányzattal rendelkező területén közel 18000 felsőoktatási intézmény múködött. Globálisan a felsőoktatásban résztvevők aránya az adott korcsoportban az 1990-es 10\%-ról 2010-re 28\%-ra nőtt. Az UNESCO adatai szerint 2010-ben több mint 150 millió volt a világon az egyetemi hallgatók száma, ami 2000-hez képest 53\%-os növekedés. Figyelemre méltó a fejlődő országok gyors felzárkózása. Az UNESCO becslései szerint egy évtizeden belül megduplázódik az egyetemi hallgatók száma a fejlett világon kívüli államokban. Ez tovább növeli a magasan képzett szakemberek kínálatát, akik sokkal „olcsóbbak” is, mint a fejlett államokbeli kollégáik. ${ }^{3}$ A felsőoktatás a fejlődő világban különösen fontos része a tudásalapú társadalom alapjait jelentő kutatás-fejlesztési infrastruktúrának.

\section{„Geoökonómia”: új diszciplína vagy elemzési módszer?}

A transzformációk következményei között tanulmányom számára különösen fontos kérdés, hogy ezek miképpen hatnak a globális térszerkezetre, valamint a társadalmi, politikai és gazdasági folyamatok közötti kölcsönhatásokra, illetve az ezekkel foglalkozó tudományos kutatásokra és diszciplínákra. Mint közismert, a geopolitika a politikai gondolkodásban meglehetősen régi. A mai szemmel is geopolitikainak tekinthető megközelítés jelen volt már az ókori civilizációkban, különösen a kínaiban és a görögben. ${ }^{4}$ A politikai döntések stratégiai jelentősége azonban a felfedezések korában Európában bontakozott ki, földrészünkön alakult ki a geopolitika sajátos diszciplínája is. Ebben az összefüggésben a geopolitika számos meghatározása ismert. Az egyik, talán legáltalánosabban elfogadott és egyszerü definíció szerint a geopolitika lényege „a földrajzi elhelyezkedés és a nemzetközi hatalmi-politikai viszonyok alakulása közti kölcsönkapcsolat" (Cohen 2009, 24.). E definíció szerint a geopolitikának mint tudományos diszciplínának egyik oszlopa a politikai földrajz, másik pedig a politikatudomány. Művelői számára különösen fontosak a földrajzi, történelmi, hatalompolitikai és funkcionális dimenziók. A földrajzi dimenzió valamely térség szélesen értelmezett fizikai környezetét jelenti (lakossága, fekvése, felszínalaktana, éghajlata, talajviszonyai, növényvilága, vízellátása, természeti kincsei, megközelíthetősége stb.). A történelmi dimenzió között az adott térség államai kialakulásának történelmi háttere, államhatárainak változásai, stratégiai fontosságát meghatározó tényezők és ezek változásai stb. említhetők. A hatalmi-politikai dimenzióba a térségre jellemző hatalmi viszonyok, a hatalmi befolyás kiterjesztésére irányuló törekvések, más térségekből kiindult politikai hatások, szövetségek, ellentétek, ezek forrásai sorolhatók. Végül pedig a funkcionális dimenziót valamilyen adott térségnek 
mint politikai egységnek vagy geostratégiai régiónak a „müködése” alkotja. E dimenzió funkcionális fontossága jellemezhető a térség szerepével is a környező államok vagy a világ más térségeinek életében, politikai-hatalmi, gazdasági viszonyaiban. Az említett dimenziókból is következik, hogy a geopolitikai viszonyok jelentősége az egyes történelmi időszakokban eltérően alakult, s ezek keretei között is gyakran változott.

Mint az előzőekben kifejtettem, a globális geopolitikai viszonyok a 21. század második évtizedében hatalmas transzformációk nyomán formálódnak. A második világháború és geopolitikai következményei lényegében a történelem ködébe vesztek. A hidegháború két világa helyébe multipoláris rendszer lépett. A két világ fogalmának megszüntével elvesztette értelmét a harmadik világ fogalma is. A fejlödő világ - vagy ahogy ma nevezik, a „felemelkedő államok” (emerging states) - új, globális fontosságú hatalmi központjai Ázsiában és LatinAmerikában formálódnak. A globális geopolitikai változásokkal összefüggő biztonsági kihívások is megváltoztak. A hatalom forrásai és gyakorlásának eszközei között döntő fontosságúvá váltak a gazdasági tényezők és eszközök.

A gazdasági hatalom bázisát természetszerủleg más tényezők befolyásolják, mint a politikai hatalomét és különösen a katonai erőét. Alkalmazásának eszközei és feltételei is sokrétűbbek. A nemzetközi rendszerben a gazdasági hatalom bázisainak hosszú ideig a földet, a természeti erőforrásokat, a munkára és hadra fogható népesség nagyságát és annak képességét tartották, hogy ellenfeleinél többet tudjon az adott állam fegyverekre és háborúkra fordítani. A globalizálódott világban ezek a tényezők továbbra is jelentősek. Fontosabbá váltak azonban azok a tényezők, amelyeket az államok vagy a vállalatok maguk teremtettek meg: az innovációk „termelésének” és befogadásának képessége, a befektetési környezetet támogató racionális szabályok, a helyes, reális és fenntartható gazdaságpolitika, a jól képzett és alkalmazkodni képes munkaerő, a fejlődést alátámasztani képes infrastruktúra, beleértve a szállítást, a kommunikációt és az energiaellátást. Nyilvánvaló, hogy a gazdasági hatalmi tényezőktől és képességektől függ a katonai erő fenntarthatósága is.

A gazdasági tényezők jelentőségének növekedése a hatalmi viszonyrendszerben döntő szerepet játszott a térviszonyok és gazdaság feltételrendszerét integráló megközelítés és az ennek nyomán megjelenő új „funkcionális” diszciplína, a geoökonómia kialakulásában. A közgazdaság-tudományban az elmúlt évtizedekben több új, „,funkcionális” vagy más tudományterületekkel összekapcsolt „transzdiszciplináris” gazdaságtan is kialakult: például a környezeti gazdaságtan, az „ökoökonómia” vagy a népesedés-gazdaságtan.

Jogos kérdésként fogalmazódik meg, hogy miben különbözik a geoökonómia a gazdaságföldrajztól. A gazdaságföldrajz „hagyományosan” a földrajztudomány egyik fontos ága vagy „alrendszere”, amely az államok, régiók, kontinensek vagy a világ gazdasági tevékenységeinek térbeli elhelyezkedését tanulmányozza. Jelentősége különösen a második világháború óta nőtt meg, a gyarmati rendszer felbomlása, a globalizáció, a világtermelés és -fogyasztás, valamint a világkeres- 
kedelem és a transznacionális társaságok nemzetközi hálózatának gyors terjedése nyomán (Sparke 2007). A geoökonómia a földrajzi tényezőkkel összefüggő államközi konfliktusokkal, ezek kezelésével, valamint a gazdasági eszközrendszer szerepével, ezek alkalmazhatóságának és alkalmazásának feltételeivel és lehetséges következményeivel foglalkozik az államok nemzetközi stratégiájában, külpolitikájában (Cowen, Smith 2009). A geoökonómia fogalmának és diszciplínájának eredetével foglalkozó kutatásoknak egyik nemzetközileg elismert művelője, a szerb Blagoje Babić (2009), a belgrádi Megatrend Egyetem Geoökonómiai Karának professzora szerint a geoökonómia fogalmát először George Renner (1942) amerikai tudós használta. Babić szerint a geoökonómia térhódításában egy másik amerikai tudós, a román származású Edward Luttwak (1990) az elméleti alapok megteremtésében fontos: úgy tekintik őt, mint a geoökonómia önálló tudományának a keresztapját. A fogalmat Luttwak 1999-es könyvében fejlesztette tovább. A Luttwak által elindított hólabda azonban nem vált lavinává: mindmáig viszonylag kevés munkát publikáltak a geoökonómiáról. Az első fontosabb munka Savona és Jean 1995-ben megjelent kötete volt. Elismerés illeti a geoökonómia terjesztéséért Oroszországban Kocetovot, fö munkáját 1999-ben és 2006-ban publikálták. Franciaországban a legfontosabb munkát Pascal Lorot írta 1999-ben. A Revue française de géoéconomie folyóiratot 1997-ben indították el, azzal a céllal, hogy tanulmányozzák a nemzetközi gazdasági és hatalmi stratégiákat. A folyóirat jelentős hozzájárulás a geoökonómia fogalmának terjesztéséhez a tudományban és a közgondolkodásban. A geoökonómiával foglalkozó jól ismert közgazdászok között két indiai is van: Jagdish Shet és Rajendra Sisodia (Sheth, Sisodia 2006).

A fenti lista feltétlenül kiegészítendő véleményem szerint a közgazdaságtudomány és gazdasági fejlődés térszerkezete (és a növekedési pólusok) kutatásával foglalkozó egyik kiváló francia tudósnak, Jacques Boudeville-nek 1966-ban megjelent írásával. Boudeville az 1960-as években a liberális növekedési pólus kialakulásával kapcsolatban használta a geoökonómiai gondolkodást, szemben a geopolitikai megközelítésekkel.

A geoökonómia fogalmát egyébként több kutató is igyekezett definiálni. Luttwak például a következő meghatározást adta: „A geoökonómia az államok közötti régi versengés új kiadása. Ilyen új versengésben az állam által biztosított tőke az ipari beruházáshoz egyenértékủ azzal, mint ha fegyverekkel lőnének; a szubvenciók egyenlők a fegyverek hatékonyságának javításával; s a piacokra való behatolás állami segítségéhez hasonlók a külföldi katonai támaszpontokról végzett hadműveletek" (Luttwak 1999, 128-129). A témában született tanulmányok túlnyomó többsége vagy Luttwak definícióját követi, vagy igyekszik hasonló szellemű, tehát valamilyen módon a geopolitikához kapcsolódó meghatározást adni, ami a globális politikai konfliktusok szempontjából lényeges. Klaus Solberg Soilen (2012) az erőforrások beépítésével és a verseny fontosságának hangsúlyozásával bővíti a definíciót. Szerinte a geoökonómia tudománya „az erőforrások térbeli, kulturális és stratégiai összefüggéseinek elemzése azzal a céllal, hogy fenntart- 
ható versenyelőnyökre lehessen szert tenni." Soilen egyébként a geoökonómiát a geopolitika logikája folytatásának tartja a globalizáció korában, s alternatív multidiszciplináris irányzatnak tekinti a közgazdaság-tudomány keretében.

Megjegyzendő, hogy a geoökonómiai megközelítések nem szorították ki a geopolitikai elemzéseket. Sokkal inkább azokkal párhuzamos vagy azokat továbbfejlesztő kutatásokat, elemzéseket és irányzatot képviselnek. Valószínű, hogy a geoökonómiai elemzés és tudományos diszciplína a jövőben nemcsak a földrajzban, a regionális tudományokban vagy a közgazdaság-tudományban játszik majd integráló szerepet, hanem a demográfiában, a szociológiában és más társadalomtudományokban is. Valamennyi tudományos diszciplína kialakulása, elfogadása, esetleges térhódítása viták sorozatában folyik. A jövő nagy kérdéseiről zajló viták nyilvánvalóan tovább alakítják a geoökonómiát is. Jelentőségét ismert tényezők támasztják alá. A 21. század közepére bolygónk lakóinak száma valószínűleg megközelíti majd a 9 milliárdot, tehát közel 30\%-kal bővül. Nem csökkenek a globális gondok. Intenzívebbé válik a migráció. Éleződni fog a versengés a vízért, valamint azokért a nyersanyagokért, amelyek készletei nem korlátlanok. Nő az államok közötti együttműködés jelentősége. A globalizáció és a regionális integrálódás folyamata, valamint közel 200 állam gazdasági törekvései, érdekviszonyai, együttműködése és versengése sokoldalúan befolyásolják a gazdasági tér problematikáját. A környezeti problémák miatt minden korábbinál fontosabbá válnak a térbeli viszonyok. A szükséges új megközelítésben minden bizonnyal lényeges lesz a geoökonómia Magyarországon is, mint transzdiszciplináris, komplex tudományterület.

\section{Jegyzetek}

1 Az 1960-as években a Föld népessége évi átlagban 2\%-kal nőtt. A legjelentősebb abszolút növekedés az 1980-as években volt, évi 86 millió fővel. Az 1960-as években egy fejlődő országbeli nő átlagosan 6 gyereket szült fogamzóképes korában. A század végére ez az érték háromra csökkent. A csökkenés az életmód megváltozásának és a fogamzásgátlók használatának volt köszönhető. A fejlődő országok jelentős részében a különböző felekezeti tilalmak ellenére nőtt a fogamzásgátlók használata. A fejlett ipari országok 70\%-os arányával szemben az afrikai nőknek még mindig csak 20\%-a használ fogamzásgátló szereket.

2 Azoknak a 65 éven felülieknek kétharmada, akik a világon eddig éltek, ma is él. A világ legöregebb országa Svédország, ahol a lakosság 18\%-a 65 éven felüli. Az átlagos fogamzóképes korú európai nő átlagban 1,7 gyereket szül. A népesség újratermeléséhez 2,1 gyerekre van szükség. Ha a német születési arányok a mai szinten maradnak (1,3 gyerek), a német lakosság 300 éven belül kihal. Írország és Izland az a két ország Európában, ahol elegendő gyerek születik a lakosság szinten tartásához. A legkevesebb gyerek Olaszországban születik. Az európaiak ma a világ lakosságának 10\%-át teszik ki, 2050-ben 4\%-ra csökken részesedésük. 2020-ra a 65 éven felüliek aránya felülmúlja a 14 éven aluliakét Európában. A férfiak várható élettartama az EUban 80 , a nőké 82,5 év. A hatvan éven felüli férfiak kevesebb mint 5\%-a munkaképtelen. Minimálisan évi 1,5\%-os egy före jutó GDP-növekedésre van szükség a jelenlegi szociális kiadások fenntartásához a következő 50 év során. A 65 éven felüliek egészségügyi kiadásai négyszer 
nagyobbak, mint a 65 éven aluliaké. Az EU lakosságának 80\%-a elfogadja azt, hogy az időskorúak eltartása társadalmi kötelesség.

3 Ázsia e téren különösen vonzó térséggé fejlődött. Kínában már ma is magasabb az egyetemi hallgatók száma, mint az Egyesült Államokban, s a különbség tovább nő. Hasonló növekedés megy végbe Indiában is 1990 óta. 2007 és 2012 között az ország ötszörösére növelte oktatási ráfordításait. Valószínű, hogy az oktatás minősége a legtöbb esetben alacsonyabb, mint az USAban vagy Nyugat-Európa egyetemein, az tény azonban, hogy Ázsia több mint kétszer annyi mérnököt „termel”, mint Amerika és Európa együttvéve; ez pedig a minőségi különbségek ellenére is lényeges tényező a globális versenyben. Figyelemre méltó az is, hogy Indiából és Kínából évente több százezer diák tanul külföldi egyetemeken; döntő többségük Észak-Amerikában, Angliában és Németországban, valamint Ausztráliában. Az USA-ban a müszaki tudományokban, a matematikában és az informatikában doktori címet szerzők közel fele külföldi, főként kínai, indiai, dél-koreai és arab. Hasonlóak az arányok az Egyesült Királyságban is. A magas képzettségű munkaerő mint versenyelőny lassan „elhagyja” a fejlett világot. Mindez növekvő mértékben befolyásolja a tudásalapú gazdaság lehetőségeit sokoldalúan hasznosítani képes nemzetközi társaságok külföldi befektetésekre vonatkozó telephelyi stratégiáit is.

4 Arisztotelész $(1943,291$.) véleménye például az volt, hogy a görögök földrajzi elhelyezkedése feljogosítja őket a világuralomra.

\section{Irodalom}

Arisztotelész (1943): Politics. Book VII. Modern Library, New York

Babić, B. S. (2009): Geo-economics - reality and science. Megatrend Review, 1., 27-54.

Boudeville, J. R. (1966): Problems of regional economic planning. Edinburgh University Press, Edinburgh Cohen, S. B. (2009): Geopolitics. The geography of international relations. Rowen and Littlefield, New York

Cowen, D., Smith, N. (2009): After geopolitics? From the geopolitical social to geoeconomics. Antipode, 1., 22-48.

Dicken, P. (2003): Global shift. Reshaping the global economic map in the 21st century. Guilford Press, New York, London

Drucker, P. F. (1999): Management challenges for the 21st century. Butterworth-Heinemann, Oxford

Кочетов, Э. Г. (2006): Геоэкономика. Освоение мирового экономического пространства. Норма, Москва

Lorot, P. (1999): Introduction à la géoéconomie. Economica, Paris

Luttwak, E. (1990): From geopolitics to geo-economics. Logic of conflict, grammar of commerce. The National Interest, Summer, 17-23.

Luttwak, E. (1999): Turbo capitalism: winners and loosers in the global economy. Harper and Collins, New York Malthus, T. R. (1798): An essay on the principle of population. J. Johnson, London

Renner, G.T. (1942): Human geography in the air age. Macmillan, New York

Savona, P., Jean, C. (1995): Geoeconomia. Il dominio dello spazio economico. FrancoAngeli, Milano

Sheth, J. N., Sisodia, R. S. (2006): Tectonic shift. The geoeconomic realignment of globalizing markets. Sage, New Delhi, London

Simai M. (2008): A világgazdaság a XXI. század forgatagában. Akadémiai Kiadó, Budapest

Soilen, K. S. (2012): Geoeconomics. Ventus Publishing, Telluride

Sparke, M. (2007): Geopolitical fears, geoeconomic hopes and the responsibilities of geography. Annals of the Association of American Geographers, 2., 338-349.

United Nations (2013): World population in 2012. United Nations, New York

World Bank (2009): World development report 2009. Reshaping economic geography. Washington 